\title{
Characterization of the nongenetic causes of variation in the calcium content of bovine milk on French farms
}

\author{
P. Gaignon, ${ }^{*}$ M. Gelé, † C. Hurtaud, ${ }^{*}$ and A. Boudon* ${ }^{* 1}$ \\ *PEGASE, INRA, Agrocampus-Ouest, 35042, Rennes, France \\ †Institut de l'Elevage, 49105, Angers, France
}

conclusion, environmental factors induce variations in milk Ca content in addition to the genetics of the cows, which to date have been identified as a main factor of variation of milk $\mathrm{Ca}$ content in dairy cows. In several of the tested conditions, increases in milk production and in the amount of Ca daily secreted in milk were associated with a decrease in milk $\mathrm{Ca}$ content as though the mammary gland operated to limit the exportation of Ca when milk production rapidly increased. This result would suggest that milk Ca content could be a biomarker of Ca regulation in dairy cows.

Key words: dairy cow, calcium, milk

\section{INTRODUCTION}

Calcium is the major mineral contained in bovine milk, with a mean content of $1.25 \mathrm{~g} / \mathrm{kg}$ (Alais, 1984). Bovine milk and dairy products are the main sources of $\mathrm{Ca}$ in the diets of many countries, especially Western diets, and account for $75 \%$ of human Ca needs in the Netherlands (Flynn and Cashman, 1997). Milk Ca content is also an important determinant of milk coagulation and cheesemaking capability (Malacarne et al., 2014). However, large variations of milk Ca content exist around the cited average of $1.25 \mathrm{~g} / \mathrm{kg}$, with contents ranging between 0.9 and $1.4 \mathrm{~g} / \mathrm{kg}$ (van Hulzen et al., 2009; Hurtaud et al., 2014; Poulsen et al., 2015; Chassaing et al., 2016). A better quantification and understanding of milk $\mathrm{Ca}$ content variation is necessary to evaluate the consequences of these variations on the amount of $\mathrm{Ca}$ contained in milk in human diets or on cheese production process. It would also allow exploration of the possibility of using milk $\mathrm{Ca}$ content as a biomarker of bone accretion and resorption in dairy cows.

Several studies showed that $\mathrm{Ca}$ secretion by mammary glands could be dependent on Ca regulation in mammals, and more specifically in cows (Horst et al., 1997; VanHouten et al., 2004). VanHouten et al. (2004) described in mice that a decrease in blood Ca, caused by decreasing diet $\mathrm{Ca}$ content, increased the expression and secretion of parathyroid hormone-related protein
Received October 24, 2017.

Accepted January 22, 2018

${ }^{1}$ Corresponding author: anne.boudon@inra.fr 
(PTHrP) and decreased the secretion of Ca into milk, resulting in a $50 \%$ decrease in milk Ca content. These effects were mediated by the Ca-sensing receptor of the mammary epithelial cell. This suggests a possibility that milk Ca could be a biomarker of some events involved in Ca regulation in cows, such as postpartum hypocalcemia or bone accretion and resorption dynamics during the lactation and gestation cycle. It is known that lactating cows undergo important cycles of bone resorption and accretion during lactation (Ekelund et al., 2006), but these cycles are difficult to quantify in large numbers of animals. The idea that milk Ca content could be a biomarker of these cycles would allow better understanding of, for instance, the consequences of mineral nutrition on those cycles or of cumulative unbalanced bone accretion and resorption during several lactations on cow longevity.

Variations in milk Ca content have been clearly related to the genetics of the cows, through systematic breed differences or high heritability within a breed (Hidiroglou and Proulx, 1982; van Hulzen et al., 2009; Buitenhuis et al., 2015; Toffanin et al., 2015b). The relationship between milk $\mathrm{Ca}$ content and cow diet, its evolution during the year, or its relationships with other effects, such as the stage of lactation or seasonality, have been less studied and have even been considered to be negligible compared with the relationship between milk Ca content and the genetics of the cows (Alais, 1984; Hermansen et al., 2005). Several studies showed an effect of lactation and seasonality on milk Ca content, but with contrasting results (Gaucheron, 2005; van Hulzen et al., 2009; Toffanin et al., 2015b; Chassaing et al., 2016). van Hulzen et al. (2009) described an increase in milk Ca content, of $0.578 \mathrm{mg} / \mathrm{kg}$ per day of lactation, throughout lactation, whereas Toffanin et al. (2015b) described a decrease of more than $100 \mathrm{mg} / \mathrm{kg}$ during d 5 to 35 and 36 to 65 of lactation, followed by a similar increase until the end of lactation. A possible reason for the discrepancies between these studies is the significant difficulty in dissociating the effects of the stage of lactation, the cows' diet, and the season.

The PhénoFinLait program (Gelé et al., 2014) consisted of surveying 945 farms between November 2009 and October 2010. The aim of our study was to use the samples and the data collected during this program to better quantify and characterize the nongenetic factors affecting variations of $\mathrm{Ca}$ content in bovine milk. Our assumption was that the high numbers of participating farms and the resulting diversity of milk production systems would allow for the dissociation and characterization of the effects of the stage of lactation, diet, and season to allow a better understanding of variations in Ca content in bovine milk.

\section{MATERIALS AND METHODS}

\section{Study Design}

The data used in our study were collected through the PhénoFinLait program, which consisted of a survey performed in the major areas of milk production in France (i.e., Alsace, Brittany, Franche-Comté, Normandy, and Pays de Loire). Between November 2009 and October 2010, 945 farms were surveyed. During this period, several visits (between 2 and 8, averaging 5 ) were performed at each farm to follow the evolution of the herd and cow diets over the course of a complete year. During each visit, interviewers collected data about the dairy cows (breed, parity, stage of lactation, stage of gestation, age of first calving, milk production) and their diet (description of the composition of the diets by using 54 variables). They also collected individual milk samples, and mid-infrared (MIR) spectra of the samples of each cow were measured in the laboratory. The survey resulted in 252,519 milk spectra, 9,180 frozen milk samples, 4,825 visits, and 63,818 dairy cows divided among the 3 main breeds in France (i.e., Holstein, Montbéliarde, and Normande) spread over 5 regions. The initial aim of the project was to characterize the effect of genomics and feeding on milk fatty acid and protein composition across the diversity of French dairy farms for 3 species (i.e., cattle, sheep, and goats; Sanchez et al., 2016). The PhénoFinLait program has been fully described by Gelé et al. (2014).

\section{Prediction of Milk Calcium Content Using MIR Spectra}

A prediction equation specific to our study was developed to predict milk Ca content from MIR spectra. To achieve this, the milk Ca contents of 292 frozen milk samples taken from the bank of samples of the PhénoFinLait program were analyzed by atomic absorption spectrometry after mineralization and dilution of the samples with nitric acid (AFNOR NF ISO 8070, 2007). Those samples were chosen to maximize the diversity of the potential factors affecting variations in $\mathrm{Ca}$ content (i.e., parity, lactation stage, breed, localization, cow diet, milk yield, and protein yield). The samples were split into 2 groups: the first group contained 205 samples for calibrating the prediction equation, whereas the second group contained 87 samples used as external data to validate the equation.

\section{Characterization of Feeding Strategies}

For each visit to each farm, the mean diet was estimated by averaging the proportions of each feed in the 
diet. To characterize the effect of seasonality, the feeding strategies of the farms were characterized over 3 periods: the winter period, from November 15 to the end of March; early summer period, from April 1 to June 15; and late summer period, from June 16 to October 15. Only farms that were investigated every period were used to characterize feeding strategies. A multiple factor analysis (MFA) was therefore performed to characterize feeding strategies (Escofier and Pagès, 1994) with R (R Development Core Team, 2013) and the package FactoMineR. An MFA is a generalization of principal component analysis for the comparison of multiple data tables (Abdi et al., 2013). For our study, each table was a group of variables describing the diet for a period and each individual was a farm. There were 3 groups for the analysis, 1 per period, each with the same 54 variables, with each variable being the proportion of a feed in the diet. As all variables had the same unit, the data were not reduced. An ascending hierarchical classification was then performed on the factor scores, using Ward's criterion to select the number of clusters. The best number of clusters was given by a high ratio of the loss of inertia between $n+1$ clusters and $n$ clusters. To confirm the results, the pseudo- $\mathrm{T}^{2}$ test was also used to select the final clusters (Nakache and Confais, 2004). Another restriction was to produce several clusters between 5 and 15 . The hypothesis was that fewer than 5 clusters was too few to represent the diversity of feeding strategies and that more than 15 clusters was too many to be characterized and differentiated. A consolidation was performed based on the results of hierarchical classification using k-means clustering and virtual centers of clusters as initial individuals.

For farms that were only represented in 2 periods, missing factor scores for the third period were input with $\mathrm{R}$ and the package miss $M D A$, using an iterative MFA (Husson and Josse, 2013). Those farms were used as supplementary individuals in the MFA, so they were not included in the characterization of feeding strategies, but it was possible to use those data for the analysis of Ca content. Supplementary farms (i.e., illustrative individuals) were affected by the nearest feeding strategy after the classification and the consolidation and before analyses of the Ca content variations. The data were checked to ensure that feeding strategy characteristics were not affected by the implemented data. Farms that were investigated for only 1 period were removed from all analyses.

\section{Statistical Analysis}

The prediction of milk Ca contents from MIR spectra was performed with a partial least square regression using the PLS procedure in SAS (SAS Institute, 2013) with the data of the calibration group (Ferrand-Calmels et al., 2014). The selection of the number of latent variables was performed using the root mean squared error of prediction with the objective of achieving the smallest possible value. This method has already been used several times to predict different minerals in milk (Soyeurt et al., 2009; Toffanin et al., 2015a). Several statistical parameters of the prediction regression were used to estimate the accuracy of the prediction: the coefficient of determination $\left(\mathbf{R}^{2} \mathbf{c v}\right)$, the validation coefficient of determination $\left(\mathbf{R}^{2} \mathbf{v}\right)$, the root mean squared error (RMSE), and the ratio of the standard error of cross-validation to standard deviation.

A mixed-model ANOVA was performed using PROC MIXED in SAS to characterize the factors affecting variations in $\mathrm{Ca}$ content. The selected model, which was the same for the 3 breeds, was

$$
\begin{gathered}
\text { Yijklm }_{i j} \mu+\text { Month of Lactation }_{i}+\text { Parity }_{j} \\
+{\text { Calendar } \text { Month }_{k}+\text { Feeding Strategy }_{l}}_{+(\text {Calendar Month } \times \text { Feeding Strategy })_{k l}} \\
+\operatorname{Herd}_{m}+\varepsilon_{i j k l m},
\end{gathered}
$$

where $\mathrm{Y}_{i j k l m}$ was a dependent variable of a cow in the herd $m$, with parity $j$ during month of lactation $i$, during the calendar month $k$, in the feeding strategy $l$, and $\varepsilon_{i j k l m}$ was the residual error. With the exception of the herd factor, which was a random factor, all other factors were fixed. For each breed, some feeding strategies were removed from the analyses, as they did not have enough data and were too unbalanced throughout the year. Data from d 1 to 8 of lactation were removed to avoid the effect of colostrum in the analysis. Data after d 360 of lactation were also removed. Parities of 5 or greater were regrouped. Cows with only 1 milk sample were removed from the analyses. The analyses were performed independently for each breed. The same model was used to characterize the effects of the same factors on daily milk production, protein content, amount of $\mathrm{Ca}$ secreted daily in milk (i.e., Ca content $x$ daily milk production), and the ratio of $\mathrm{Ca}$ content to protein content.

Because of the large amount of data gathered in the data basis, $P$-values could easily be low $(<0.001)$. Thus, the effect size (ES) of each simple fixed factor included in the ANOVA model for all explicated variables was also estimated according to the formula given by Cohen (1988):

$$
\mathrm{ES}=\frac{\sigma_{m}}{\sigma}
$$


where $\sigma$ was the standard deviation of the overall breed for the considered character, and $\sigma_{m}$ was the standard deviation due to the considered effect, and defined as

$$
\sigma_{m}=\sqrt{\sum_{i=1}^{I} p_{i}\left(y_{i}-\bar{y}\right)^{2}}
$$

where $I$ was the number of levels of the considered factor $m, p_{i}$ the proportion of the total population characterized with the $i$ th level of factor $m, y_{i}$ the mean for the $i$-th level and $\bar{y}$ the corrected mean of overall population. The ES of the interaction between calendar month and feeding strategy and of the combined effects of feeding strategy, calendar month, and the interaction between both were also estimated according to the modifications of the formulae suggested by Cohen (1988). The combined effects of feeding strategy, calendar month, and the interaction between those factors are described as combined effects in the following sections.

\section{RESULTS}

\section{Prediction of Milk Calcium Content Using MIR Spectra}

The partial least squares regression resulted in the use of 11 partial least squares. The quality of prediction was good, with high coefficients of determination for both calibration and validation. It resulted in an $\mathrm{R}^{2} \mathrm{Cv}$ of 0.75 for the calibration and an $\mathrm{R}^{2} \mathrm{v}$ of 0.80 for the validation (Table 1). The slope of the regression between the measured and predicted values was close to 1 in both cases, with values between 0.96 and 1.00. The RMSE was 56.0 for the calibration and 44.5 for the validation. The ratio of the standard error of cross-validation to standard deviation was always above 2.00, meaning that the accuracy of prediction was good.

\section{Effects of Stage of Lactation and Parity}

The numbers of data points involved in the mixed model we used were $75,120,59,595$, and 77,443 for the Holstein, Montbéliarde, and Normande breeds, respectively. The 3 breeds have very similar distributions of dates of calving during the survey period, with a maximum frequency of calving between September and January (Figure 1). The difference in the mean stages of lactation at each visit between the 3 breeds only exceeded $15 \mathrm{~d}$ in November, with a difference of $25 \mathrm{~d}$ between Holsteins and Montbéliardes for that month (Figure 2). For the 3 breeds, the mean stage of lactation increased between January and July, from d 110 to 205 of lactation. The correlation between stage of lactation (in days) and visit calendar date was low $\left(\mathrm{R}^{2}\right.$ $<0.14$ within every breed), and these variables were considered as independent. This was also illustrated by the low differences between minimum and maximum average stages of lactation between calendar months (less than 100 d, Figure 2); therefore, both variables were included in the mixed models.

Within each breed, Ca content was affected by the stage of lactation $(\mathrm{ES}=0.33$ for Holstein, 0.35 for Montbéliarde, and 0.21 for Normande; $P<0.0001$; Figure 3), with an important range of variation between months of lactation. For the 3 breeds, Ca content decreased between the first and second months of lactation, with the greatest decrease, $80.3 \pm 1.8 \mathrm{mg} / \mathrm{kg}(-6.6 \%$ of the mean of the first month), in Ca content in the Montbéliardes and the smallest decrease, $39.3 \pm 1.7 \mathrm{mg} / \mathrm{kg}$ $(-5.7 \%$ of the mean of first month), in the Normandes. The lowest $\mathrm{Ca}$ contents were observed between mo 2 and 4 of lactation; Ca content then increased from mo 5 of lactation until the end of lactation, reaching values as high as or higher than those observed during mo 1 of lactation. The range of variation of Ca content in milk during lactation was greater for Holsteins $(110.7$ $\pm 2.6 \mathrm{mg} / \mathrm{kg}$ between mo 3 and 12 of lactation; i.e., $9 \%$ variation of Holstein milk Ca content mean) than for

Table 1. Results of Ca content $(\mathrm{mg} / \mathrm{kg})$ prediction from mid-infrared spectra with partial least squares regression

\begin{tabular}{lcc}
\hline Item & 1st group (calibration) & 2nd group (validation) \\
\hline $\mathrm{N}$ & 205 & 87 \\
$\mathrm{M}$ ean $(\mathrm{mg} / \mathrm{kg})$ & $1,235.2$ & $1,239.1$ \\
$\mathrm{SD}$ & 112.5 & 99.4 \\
Predicted mean $(\mathrm{mg} / \mathrm{kg})$ & $1,235.2$ & $1,231.0$ \\
$\mathrm{R}^{2}$ & 0.75 & 0.80 \\
Root mean squared error $_{\mathrm{RPD}^{1}}$ & 56.0 & 45.5 \\
\hline
\end{tabular}

${ }^{1} \mathrm{RPD}=$ ratio of the standard error of cross-validation to standard deviation. 


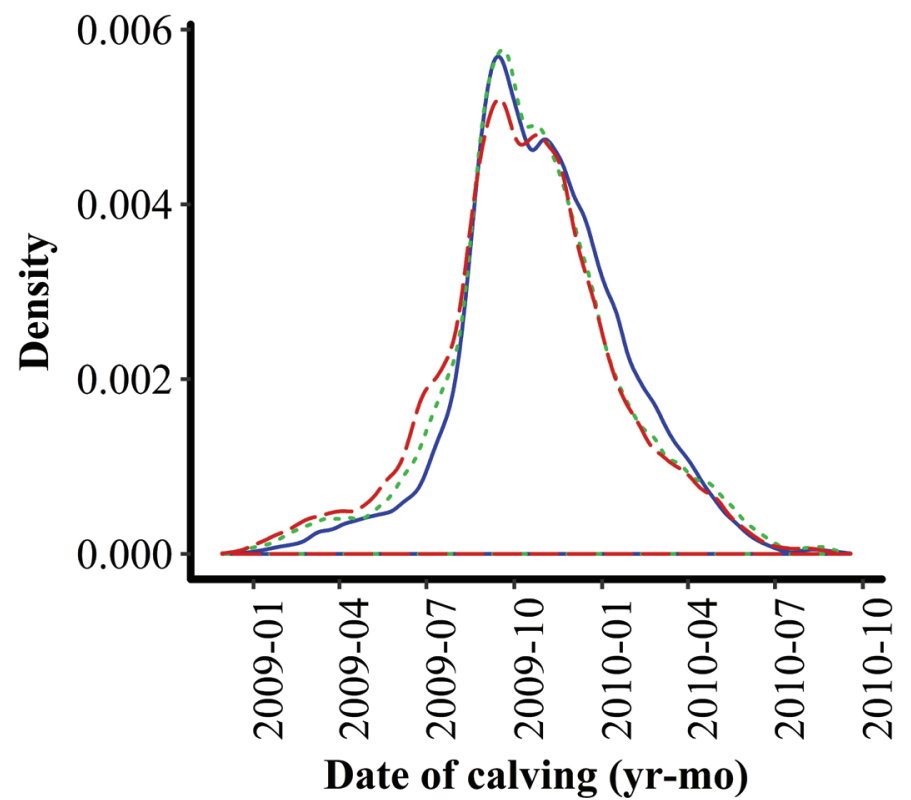

Figure 1. Frequency distribution of the dates of calving during the survey period for Holstein (dashed line), Montbéliarde (solid line), and Normande (dotted line). Color version available online.

the 2 other breeds $(66.6 \pm 2.9 \mathrm{mg} / \mathrm{kg}, 5.1 \%$ variation of breed mean, between mo 3 and 12 of lactation for Normandes; $98.9 \pm 1.7 \mathrm{mg} / \mathrm{kg}, 8.0 \%$ variation of breed mean, between mo 1 and 4 of lactation for Montbéliardes). In contrast to milk Ca content, the amount of Ca secreted daily in milk decreased throughout lacta-

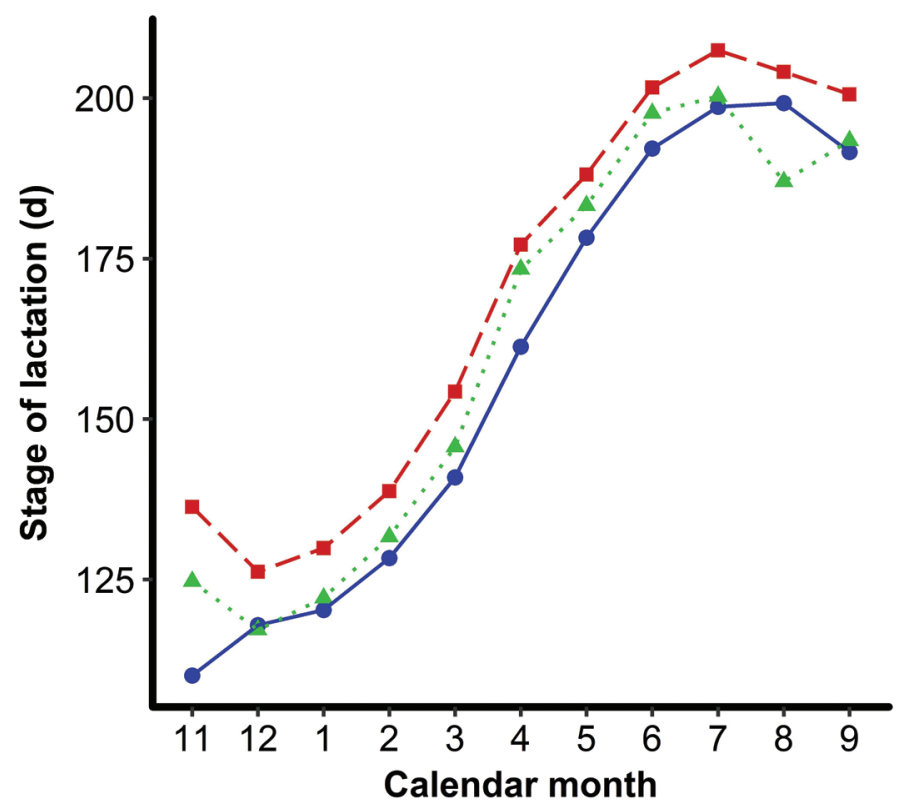

Figure 2. Evolution of the mean stage of lactation of cows during the visits for Holstein (dashed line), Montbéliarde (solid line), and Normande (dotted line). Color version available online. tion regardless of the breed $(\mathrm{ES}=0.47$ for Holstein, 0.56 for Montbéliarde, and 0.59 for Normande; Figure $3 \mathrm{~B}$ ) and was always highest in Holsteins and lowest in Normandes, with intermediate values in Montbéliardes. These results were linked to milk production, which was highest in Holsteins, with a peak at $33.7 \mathrm{~kg} / \mathrm{d}$, whereas Normandes and Montbéliardes had maximum milk productions of 27.3 and $30.2 \mathrm{~kg} / \mathrm{d}$, respectively. For Holsteins and Montbéliardes, milk production increased between mo 1 and 2 of lactation and then decreased throughout the rest of the lactation period, whereas milk production decreased throughout the entire lactation period in Normandes $(\mathrm{ES}=0.54$ for Holstein, 0.59 for Montbéliarde, 0.62 for Normande; Figure $3 \mathrm{~A}$ ).

The milk Ca content decreased with parity for all breeds ( $\mathrm{ES}=0.10$ for Holstein and Montbéliarde, 0.16 for Normande; $P<0.0001$; Table 2). The difference between lactation 1 and $\geq 5$ was approximately $30 \mathrm{mg} /$ $\mathrm{kg}$, which represents 2.3 to $2.4 \%$ of the average milk Ca content, depending on the breed. In Normandes, the maximum difference between lactation 1 and $\geq 5$ was $36.8 \pm 1.3 \mathrm{mg} / \mathrm{kg}$, which represents $2.8 \%$ of the average milk Ca content. Milk production and the amount of Ca secreted daily in milk increased between parities, with the sharpest increase occurring between parities 1 and 2 for the 3 breeds (data not shown). In contrast, the decrease in milk Ca content was not consistently greater during this period.

\section{Characterization of Feeding Strategies}

Of the 945 farms involved in the survey, 627 were visited at least once during each of the 3 defined periods and then retained in the analysis used to characterize the feeding strategies. Two hundred forty-seven farms were visited at least once during 2 of the 3 defined periods and were used as supplementary individuals after missing factors had been assessed, whereas 40 farms were removed completely because they were visited during only 1 of the 3 defined periods. Some variables and, more specifically, some feed proportions in the diet were removed for specific periods because they did not vary between farms and were null for those periods.

The first 3 dimensions of the MFA, respectively, explained 50.6, 13.0, and 8.6\% of the inertia. After the 10th dimension, each factorial axis explained less than $1 \%$ of the inertia. The first dimension contrasted corn silage for the 3 periods with hay during the winter period and pasture during the early and late summer periods. The second dimension contrasted mixed hay in the winter period and grass pasture in the early summer period with winter corn silage and mixed pasture in the early summer period. The third dimension contrasted 2 kinds 

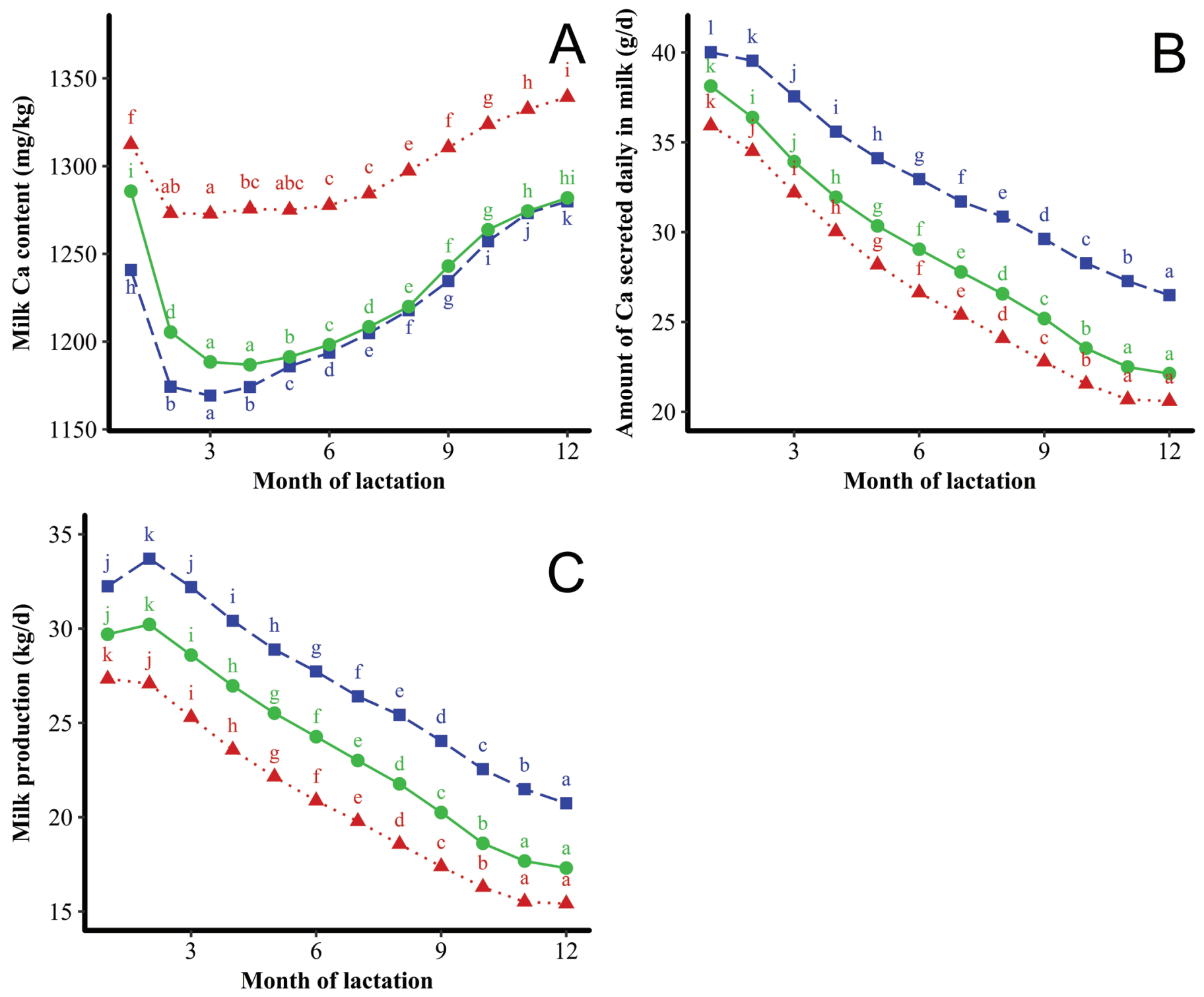

Figure 3. Effect of the stage of lactation, within each breed, on (A) milk Ca content, (B) milk production, and (C) amount of Ca secreted daily in milk for Holstein $(\mathbf{\square})$, Montbéliarde $(\mathbf{)})$, and Normande $(\boldsymbol{\Delta})$. Letters (a-l) indicate the results of comparison between the stages of lactation within a breed; different letters indicate significant differences in Ca content $(P<0.001)$. Color version available online.

Table 2. Effect of parity $(P<0.0001)$ on milk Ca content $(\mathrm{mg} / \mathrm{kg})$ for each breed

\begin{tabular}{lccc}
\hline Parity & Holstein & Montbéliarde & Normande \\
\hline 1 & $1,230.9 \pm 1.7^{\mathrm{e}}$ & $1,243.6 \pm 2.3^{\mathrm{d}}$ & $1,316.1 \pm 1.6^{\mathrm{d}}$ \\
2 & $1,223.6 \pm 1.7^{\mathrm{d}}$ & $1,230.8 \pm 2.4^{\mathrm{c}}$ & $1,316.0 \pm 1.7^{\mathrm{d}}$ \\
3 & $1,216.8 \pm 1.8^{\mathrm{c}}$ & $1,224.6 \pm 2.4^{\mathrm{b}}$ & $1,293.4 \pm 1.7^{\mathrm{c}}$ \\
4 & $1,211.0 \pm 1.9^{\mathrm{b}}$ & $1,224.5 \pm 2.5^{\mathrm{b}}$ & $1,284.6 \pm 1.8^{\mathrm{b}}$ \\
$5+$ & $1,203.5 \pm 2.0^{\mathrm{a}}$ & $1,221.4 \pm 2.4^{\mathrm{a}}$ & $1,279.3 \pm 1.8^{\mathrm{a}}$ \\
\hline
\end{tabular}

${ }^{\mathrm{a}-\mathrm{e}}$ Letters indicate the results of comparison between parities within a breed. Different letters indicate significant differences in Ca content $(P<0.001)$. of hay in the winter period, field-cured and barn-dried. The construction of the principal components was mostly affected by the variables corresponding to the proportions of forage included in the diet. One reason for this was that the data were not scaled to the unit and forages were the components of the diet with the highest proportion. Corn silage was important in the construction of principal components for the 3 periods, but hay was only important for the winter period and pasture for the early and late summer periods. Most of the proportions of feed that were less than $1 \%$ of the diets (as feed basis) did not contribute to the construction of principal components. 
Classification was performed on the first 40 principal components of the MFA, corresponding to more than $99 \%$ of the initial inertia. Classification resulted in 6 feeding strategies. The ratio of relative loss of inertia for $\mathrm{n}+1$ clusters on $\mathrm{n}$ clusters was the highest for 6 clusters. At the same time, the pseudo- $\mathrm{T}^{2}$ test showed an increase of $50 \%$ from 6 to 7 feeding strategies, the highest possible in our range of restriction. Thus, there was a local minimum with a large increase afterward, which confirmed the first results for the number of feeding strategies. They were mostly distinguished by the evolution of forage in the diet throughout the 3 periods. Descriptions of the feeding strategies over the survey period are summarized in Figure 4.

Strategies were named according to the relative importance of the main forages and the distribution of their contribution to the diet during the year or according to specific use of forages during a given period. The strategies "grazing and FC hay" and "grazing and BD hay" represented feed systems based on grazed pasture during the early and late summer periods and on fieldcured (FC) or barn-dried (BD) hay during the winter period. More than $90 \%$ of farms described by these strategies were in the northeastern part of France, more precisely in Franche-Comté, with almost exclusively Montbéliardes. In this area, most dairy farms produce Protected Designation of Origin cheeses with specifications prohibiting corn silage. Additionally, more than $75 \%$ of all organic farms involved in the survey were described by these 2 feeding strategies. The proportion of organic farms that used these 2 strategies was $15 \%$, whereas for all the farms, it was only approximately $5 \%$. The strategy "maximum grazing" consisted of a maximal use of grazing in early and late summer periods followed by diets based on corn silage during the winter period. This strategy is under-represented in FrancheComté, but at least 4,000 milk samples were classified in this strategy for each of the 3 breeds. "Maximum grazing" was the counterpart of the 2 previous feeding strategies for other regions of France, with corn silage instead of hay in winter. The strategies "grazing and FC hay," "grazing and BD hay," and "maximum grazing" included a large proportion of grazing as forage in the summer periods, but $80 \%$ of farms in the "grazing and FC hay" and "grazing and BD" hay strategies were in Franche-Comté whereas $89 \%$ of farms in the "maximum grazing" were in western regions. The strategy grazing and corn silage was based on corn silage, but with lower contributions from pasture than for the maximum grazing strategy (28 and $61 \%$ of pasture in late summer period for strategies "grazing and corn silage" and "maximum grazing," respectively). The strategy "grazing and corn silage" was more represented in north- western France, but this strategy was well represented in each breed. The strategy "corn silage" was based on this forage for all periods. It was highly represented in the extreme northeast of France, in Alsace, where at least $65 \%$ of farms were classified in this strategy, even though this strategy was represented in all regions and was well represented in each breed. A gradient in the diet compositions, from pasture-based diets to corn silage-based diets in the early and late summer periods, was discernable for the 3 strategies "maximum grazing," "grazing and corn silage," and "corn silage." The strategy "grazed temporary pasture" was based on nonpermanent pasture during the early and late summer periods and on corn silage and a substantial amount of grass silage in the winter. It was associated with a use of temporary pasture, which was over-represented in western regions of France (21\% of farms in those regions characterized by the strategy versus $6 \%$ on average for all studied regions). It was under-represented in Montbéliarde cows, with only $0.71 \%$ of the samples collected from Montbéliarde cows classified in this strategy (Table 3).

\section{Effect of Feeding Strategy and Calendar Month on Milk Calcium Content}

For the mixed-model analysis within breed, underrepresented feeding strategies (fewer than 2,000 milk samples, Table 3) were removed. Thus, the strategies "grazing and FC hay" and "grazing and BD hay" were not included for Holsteins and Normandes, and the strategy "grazed temporary pasture" was not included for Montbéliardes. Feeding strategy, calendar month, and their interaction clearly affected milk Ca content $(P<0.0001$; Figure 5), but, more generally, all effects included in the mixed model were highly significant $(P$ $<0.0001$; Table 2, Figure 3) for every predicted variable. Feeding strategy had a higher $P$-value in Holsteins $(\mathrm{ES}=0.05 ; P=0.0012) . P$-values were only given if they were higher than 0.0001 , but ES were given because they brought information about the variability due to each effect. For the 3 breeds, model milk Ca content estimations were more accurate between December and July with low mean standard errors, whereas at the beginning and the end of the investigation the mean standard errors were higher due to smaller amounts of data. For instance, the mean standard error of the mean milk Ca content for all the feeding strategies was 9.07 and $10.18 \mathrm{mg} / \mathrm{kg}$ for Holsteins in August and September, respectively, whereas it did not exceed $6 \mathrm{mg} /$ $\mathrm{kg}$ for the other months. The results from August and September will be less discussed, as the adjustment of the models was not as good as for the other calendar 
Grazing \& FC hay

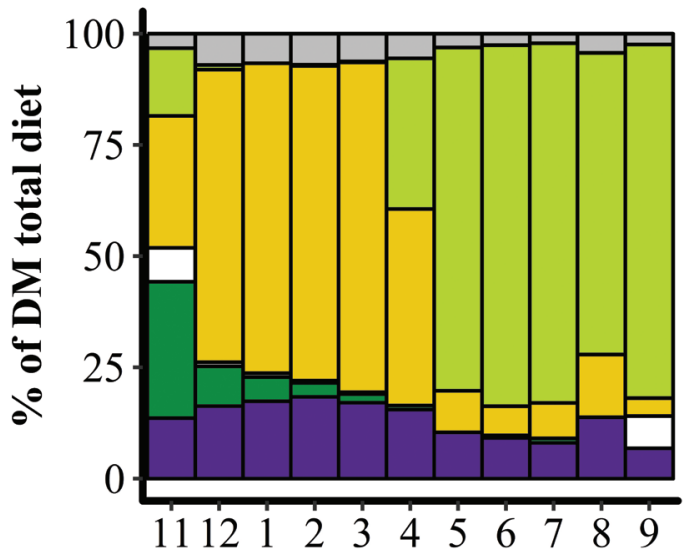

Maximum grazing

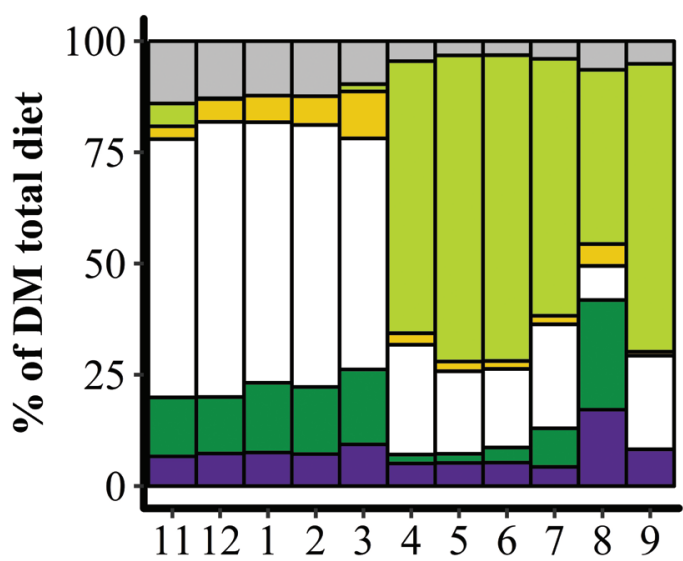

Grazing and corn silage

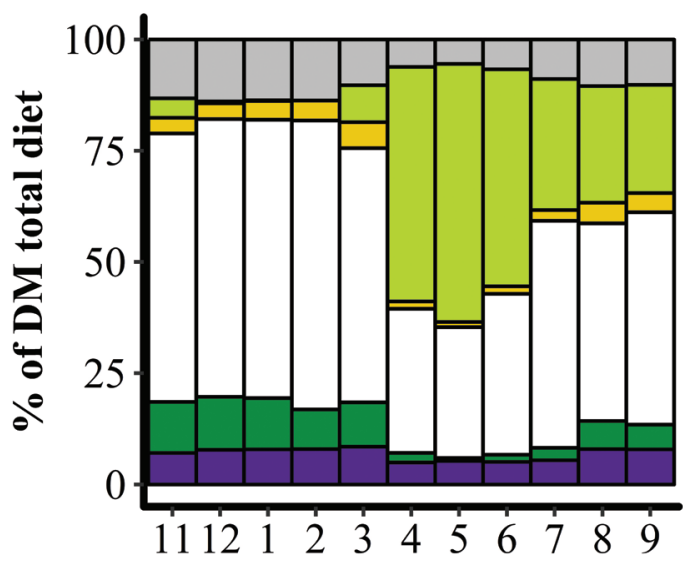

Grazing \& BD hay

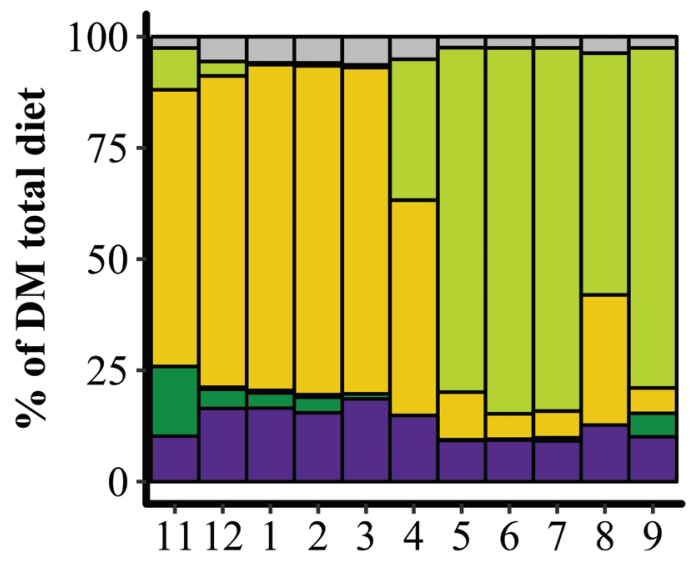

Grazed temporary pasture
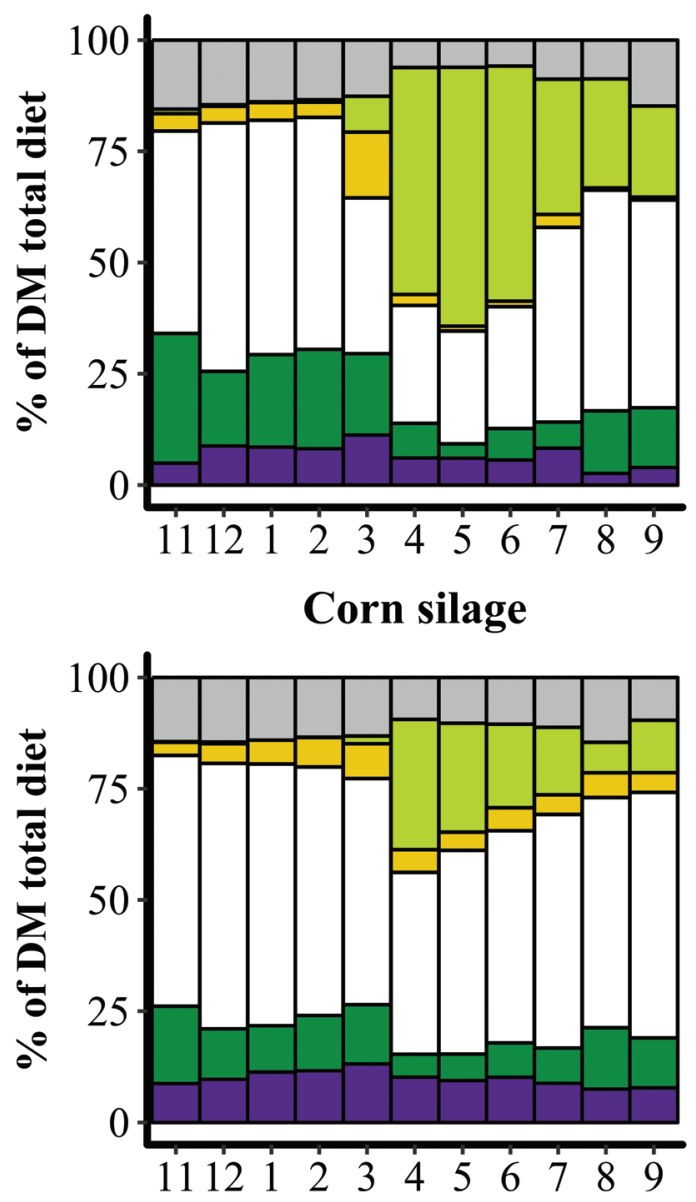

Figure 4. Evolution of the mean diet during the survey period for the 6 feeding strategies (gray/purple $=$ feed concentrate and minerals; black/dark green = grass silage; white = corn silage; gray with black stripes/yellow = hay; black with white stripes/light green = grass; white with black stripes/gray $=$ oil meal and oleaginous seeds). $\mathrm{FC}=$ field-cured; $\mathrm{BD}=$ barn-dried. Color version available online.

months. For each breed, the differences in the mean stages of lactation between the feeding strategies and within each calendar month were low (data not shown).
For the 3 breeds, Ca content clearly decreased between March and May, regardless of feeding strategy, and started increasing from July onwards (ES of calendar 
Table 3. Distribution of milk samples among breeds and feeding strategies

\begin{tabular}{lrcc}
\hline & \multicolumn{3}{c}{ Breed } \\
\cline { 2 - 4 } Feeding strategy & Holstein & Montbéliarde & Normande \\
\hline Grazing and field-cured hay & 1,529 & 23,042 & 1,270 \\
Grazing and barn-dried hay & 387 & 14,363 & 1,674 \\
Maximum grazing & 9,857 & 4,318 & 22,443 \\
Grazing and corn silage & 30,592 & 7,443 & 40,251 \\
Corn silage & 27,538 & 10,429 & 7,496 \\
Grazed temporary pasture & 7,409 & 430 & 7,253 \\
\hline
\end{tabular}

month $=0.24$ for Holstein and Montbéliarde, 0.16 for Normande; Figure 5). The period between March and May corresponded to pasture turn-out for all feeding strategies (Figure 4), whereas the proportion of grazed pasture started to decline after July for all strategies except those combining grazing and hay ("grazing and FC hay" and "grazing and BD hay").

For Holsteins, milk $\mathrm{Ca}$ content in the winter (i.e., mainly January and February) was higher with the strategy "grazed temporary pasture" compared with the other strategies, whereas in the summer (i.e., in June and July) it was higher with the strategy "corn silage" compared with the other strategies (ES of feeding strategy $=0.05$; Figure 5). The drop in Ca content between March and June was higher for strategies based on higher proportions of pasture. The largest decrease was for "maximum grazing," with a decrease of $86.1 \pm$ $5.3 \mathrm{mg} / \mathrm{kg}(-6.9 \%$ of the mean of the feeding strategy in March) over this period, whereas "grazed temporary pasture" showed a decrease of only $22.7 \pm 2.4 \mathrm{mg} / \mathrm{kg}$ $(-1.9 \%$; ES of combined effects $=0.25)$.

For Montbéliardes, the strategies "grazing and FC hay" and "grazing and BD hay" resulted in lower milk Ca content from November to April compared with the 3 other strategies (i.e., "corn silage," "grazing and corn silage," and "maximum grazing"). The difference between these 2 specific feeding strategies and the others was approximately $50 \mathrm{mg} / \mathrm{kg}$ ( $4.1 \%$ of the breed mean) for this period. In winter, these 2 strategies were based on hay, whereas the 3 other feeding strategies were based on corn silage (ES of feeding strategy = 0.16 ; Figure 4). The decrease between the winter period and the early summer period was less important for the strategies "grazing and FC hay" and "grazing and BD hay" than for the other strategies (ES of interaction = 0.13 , combined effects $=0.31$; Figure 5 ). After turn-out to pasture, in April, these 2 strategies were not different from the others. Between April and June, higher values were obtained for strategies based on a higher proportion of corn silage ("grazing and corn silage" and "corn silage") rather than grazed pasture ("grazing and BD hay," "grazing and FC hay," and "maximum grazing").
For Normandes, differences between feeding strategies were less important than for the other 2 breeds $(\mathrm{ES}=0.05$ for feeding strategy and interaction, $\mathrm{ES}=$ 0.18 for combined effects). Only the strategy "grazed temporary pasture" resulted in lower milk Ca content from November to June compared with other strategies. Differences between the 3 other strategies were rarely more than $30 \mathrm{mg} / \mathrm{kg}$ ( $2 \%$ of breed mean) within a calendar month and were rarely significant, except during the diet transition in March and April. For Holsteins and Montbéliardes, higher $\mathrm{Ca}$ content was obtained with a higher proportion of corn silage rather than pasture, and these effects were greater for Holstein and Montbéliarde than for Normande.

\section{Effect of Feeding Strategy and Calendar Month on Milk Production and Amount of Calcium Secreted Daily in Milk}

For Holsteins, milk production increased from November to April, regardless of feeding strategy, and then started decreasing until August (ES of calendar month $=0.13$; Figure $6 \mathrm{~A})$. Milk production was higher with the feeding strategy "corn silage" from December to July, except for April, and was lower with the feeding strategy "maximum grazing" (ES of feeding strategy = 0.15 , interaction $=0.05$, and combined effects $=0.20$ ) . The higher the proportion of corn silage in the diet was, the higher the milk production. The amount of Ca secreted daily in milk increased from November to April, decreased until August, and then increased as the proportion of corn silage in the diet increased (Figure $6 \mathrm{~B})$. However, the relative increase in the amount of $\mathrm{Ca}$ secreted daily in milk between January and April was less important than the increase in milk production. For instance, for the strategy "maximum grazing," milk production showed an increase of $12.3 \%$, whereas the amount of $\mathrm{Ca}$ secreted daily in milk showed an increase of $7 \%$, which was concomitant with an important drop in milk Ca content. The same trends were observed for the other strategies but with lower amplitudes. Similar trends were also observed for Montbéliardes and Normandes (data not shown; $\mathrm{ES}$ of combined effects $=0.24$ for both breeds).

\section{Effect of Feeding Strategies on Milk Protein Content and $\mathrm{Ca}$ Content-to-Protein Content Ratio}

Milk protein content was significantly affected by the feeding strategy, but the differences did not exceed 1 $\mathrm{g} / \mathrm{kg}$ in Holstein cows in a given month (ES of feeding strategy $=0.03$; Figure 7). For Montbéliardes and Normandes, the differences between feeding strategies in a given month exceeded $1 \mathrm{~g} / \mathrm{kg}$ only in August, Septem- 

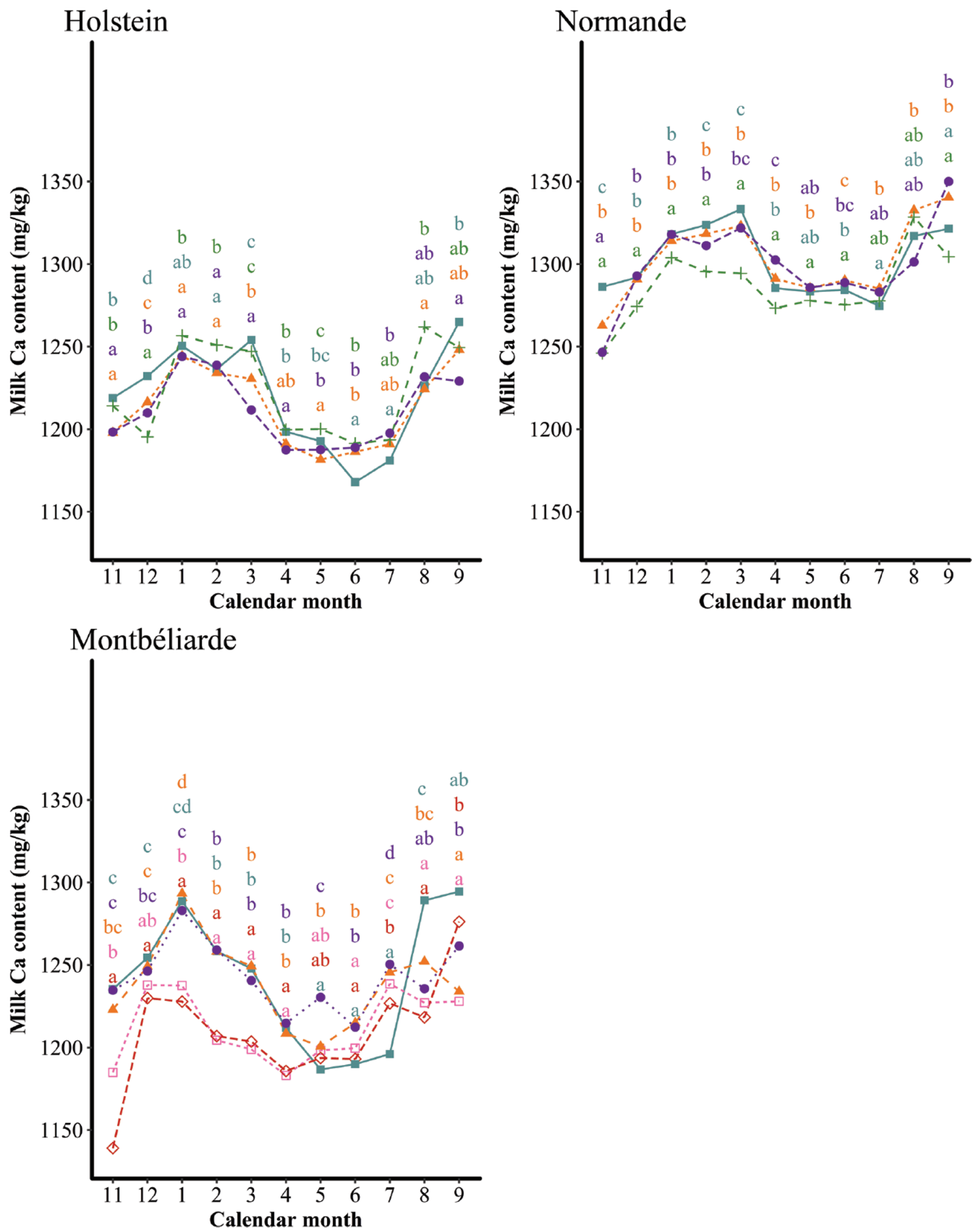

Figure 5. Effect of feeding strategy and calendar month on milk Ca content for the 3 breeds. Letters (a-d) represent each feeding strategy over a side-by-side comparison within a month $(P<0.0001)$ : grazing and field-cured hay $(\diamond)$, grazing barn-dried hay $(\square)$, maximum grazing $(\boldsymbol{\square})$, grazing and corn silage $(\boldsymbol{\Lambda})$, corn silage $(\bullet)$, grazed temporary pasture $(+)$. Color version available online. 

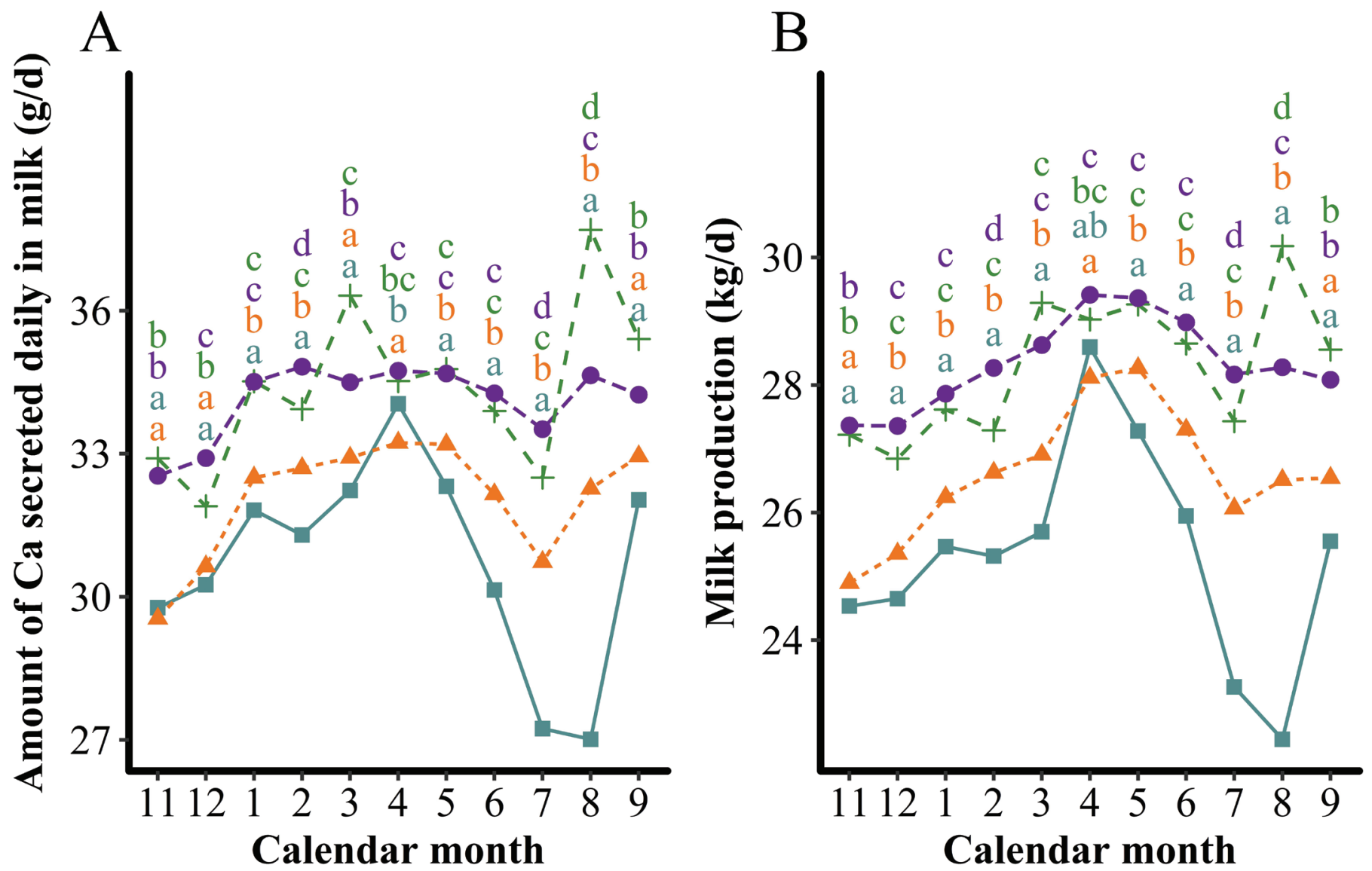

Figure 6. Effect of calendar month and feeding strategy in Holstein on (A) amount of Ca secreted in milk and (B) milk production. Letters (a-d) represent each feeding strategy over a side-by-side comparison within a month $(P<0.0001)$ : maximum grazing $(\boldsymbol{\square})$, grazing and corn silage $(\boldsymbol{\Lambda})$, corn silage $(\bullet)$, grazed temporary pasture $(+)$. Color version available online.

ber, and November, when estimations were less accurate (data not shown; ES of feeding strategy $=0.08$ for Normande and 0.09 for Montbéliarde). Protein content decreased from November to July and then increased until the end of the survey period. The ratio of $\mathrm{Ca}$ content to protein content was clearly affected by the calendar month, with variations greater than $2 \mathrm{mg} / \mathrm{g}$ between months (ES of calendar month $=0.18$ for Holstein, 0.24 for Montbéliarde, and 0.20 for Normande). In Holsteins, it increased slightly between December and March and decreased sharply between March and April due to the Ca content in milk. After April, the ratio started decreasing again until July, when protein content was lowest for every feeding strategy.

The feeding strategy always affected the dynamics of the ratio of milk Ca content to protein content and of the milk protein content for the 3 breeds (ES for combined effect $=0.19$ for Holstein, 0.32 for Montbéliarde, 0.22 for Normande; Figure 7 for Holsteins, data not shown for Montbéliardes and Normandes). For Normandes, "maximum grazing" had the lowest protein content for the majority of the survey period, leading to the highest ratio of milk Ca content to protein content compared with the other feeding strategies; however, variations due to calendar month were still more important than those due to feeding strategy. For Montbéliardes, the trends were the same as they were for Holsteins, but the variation range was greater, between 35.2 and $40.5 \mathrm{mg} / \mathrm{g}$ (14\% of variation of breed mean) from December to July. "Grazing and BD hay" and "grazing and FC hay" had lower ratios in winter than the other feeding strategies due to lower milk Ca content, with a difference of at least $1 \mathrm{mg} / \mathrm{g}$ for that season.

\section{DISCUSSION}

\section{Quality of MIR Prediction and Relevance of the PhénoFinLait Program}

The quality of prediction of the Ca content in milk was similar to those that were performed previously 

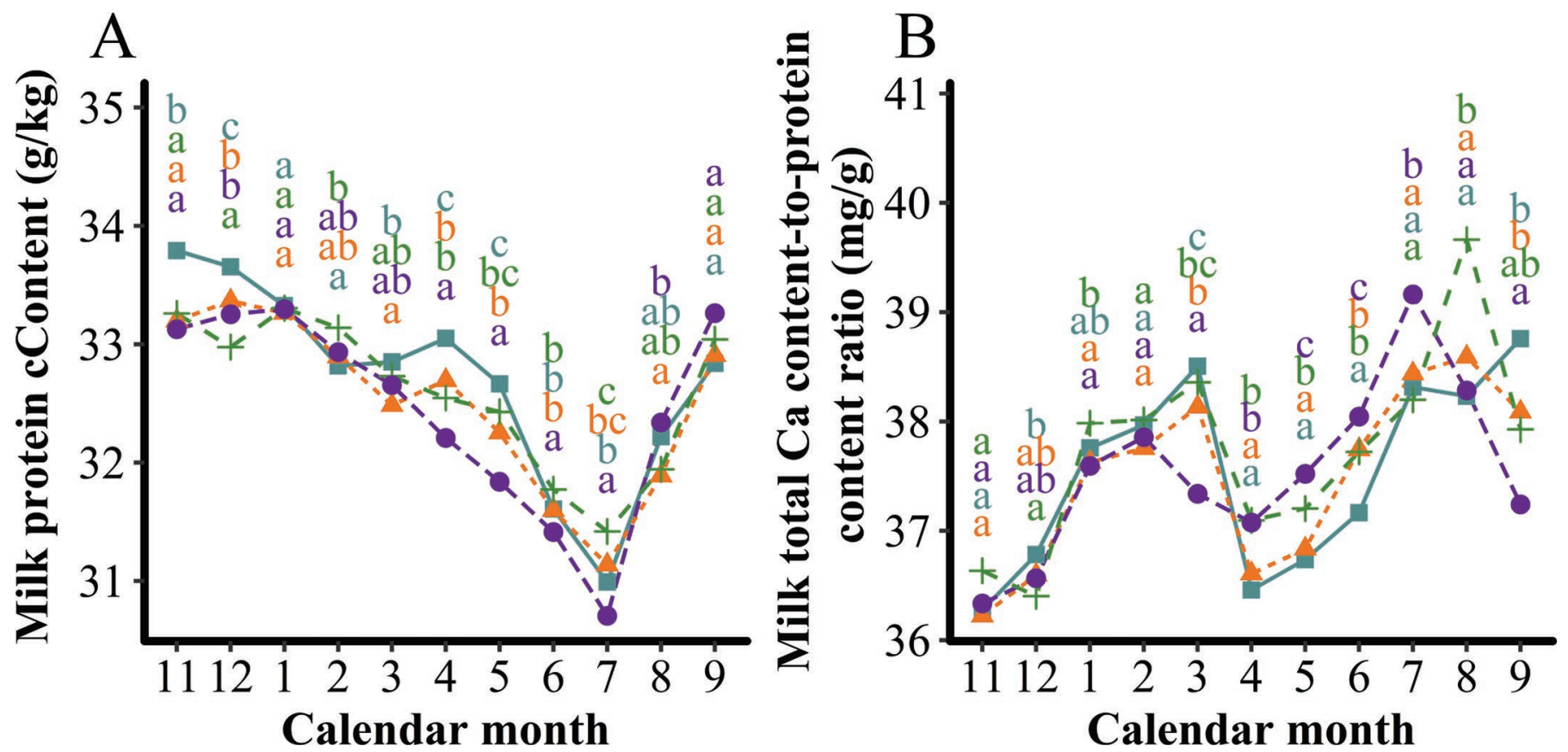

Figure 7. Effect of calendar month and feeding strategy in Holsteins on (A) protein content in milk and (B) the ratio of Ca content to protein content in milk: maximum grazing $(\mathbf{\square})$, grazing and corn silage $(\mathbf{\Lambda})$, corn silage $(\mathbf{\bullet})$, grazed temporary pasture $(+)$. Different letters $(\mathrm{a}-\mathrm{c})$ indicate significant differences between feeding strategies within a calendar month $(P<0.001)$. Color version available online.

(Soyeurt et al., 2009; Toffanin et al., 2015a). The mean milk Ca content we observed in this study (i.e., 1,230 $\mathrm{mg} / \mathrm{kg}$ ) was in the same order of magnitude as those obtained by Soyeurt et al. (2009) and Toffanin et al. (2015a) in the databases they used to develop MIR prediction equations. The $\mathrm{R}^{2} \mathrm{cv}$ we obtained was similar to that of Toffanin et al. (2015a; 0.75), but was lower than that obtained by Soyeurt et al. (2009; 0.97). The better $R^{2}$ cv of Soyeurt et al. (2009) is likely linked with their validation data that were split into 2 distinct and extreme groups, with a range of approximately 400 $\mathrm{mg} / \mathrm{kg}$ without data. This should have increased the $\mathrm{R}^{2} \mathrm{cv}$ of the regression with data that were not normally distributed, according to the hypothesis of the generalized linear model; RMSE was not reported by Soyeurt et al. (2009). Toffanin et al. (2015a) had an RMSE of approximately 85, depending on the software used, whereas ours did not exceed 56. The large number of samples used in our study, 292 vs. 203 for Toffanin et al. (2015a) and 87 for Soyeurt et al. (2009), did not seem to increase the quality of prediction but was necessary to obtain a large panel for the source of variability in milk Ca content. It may have increased the inference in the prediction equation.

The PhénoFinLait program constituted a very good opportunity to study nongenetic factors affecting variations of Ca content in milk. Compared with previously published studies that aimed to characterize the variability of milk Ca content (van Hulzen et al., 2009; Poulsen et al., 2015; Chassaing et al., 2016), our study had the disadvantage of using MIR predictions of milk Ca content instead of direct measurements, as in Toffanin et al. (2015b), but had the advantage of relying on individual milk sampling, several times during the year, from a large number of cows and with a high diversity of diets with relatively well-described compositions. van Hulzen et al. (2009) and Toffanin et al. (2015b) both worked on individual samples of milk, but their studies did not involve more than 2,500 cows, and each cow was only sampled once per study. In contrast, the PhénoFinLait program involved over 50,000 cows with several samples during the same lactation. Toffanin et al. (2015b) did not give any information about cow diet, and Van Hulzen et al. (2009) had only 1 diet for all cows in the study. van Hulzen et al. (2009) only had 1 sampling date, whereas the sampling lasted almost $1 \mathrm{yr}$ for Toffanin et al. (2015b), although no effect of season was included in the latter study. Only Chassaing et al. (2016) included the effect of seasonality, with 5 periods of sampling, and included diet, but it was less well described than in PhénoFinLait. However, that study was done on tank milk and it was not possible to assess the effects of the stage of lactation or parity on milk Ca content. 


\section{Effects of Breed, Stage of Lactation, and Parity on Milk Ca Content}

The effect of breed, and more generally of the genetics of cows, on milk Ca content is well known and has been described several times (Hermansen et al., 2005; van Hulzen et al., 2009; Chassaing et al., 2016). For instance, Jersey cows have a higher milk Ca content than Holstein cows (Hermansen et al., 2005), and high heritability of milk Ca content was found in Holsteins with a value of 0.57 (van Hulzen et al., 2009). However, as milks were sampled on the same date, from only primiparous cows, and as cows were fed the same ration, this heritability may have been overestimated. In our study, we observed large differences in milk Ca content between Holstein, Montbéliarde, and Normande cows, with higher values for Normandes.

The effect of the stage of lactation on milk Ca content had already been described in dairy cows (Kaufmaan and Hagemeister, 1987; Gaucheron, 2005; Hermansen et al., 2005). A sharp decrease between the first 2 mo of lactation has often been described, followed by a smooth increase until the end of lactation (Kaufmaan and Hagemeister, 1987). Our results confirmed these dynamics but showed different orders of magnitude between breeds, with Holstein cows having the largest decrease in milk Ca content during the beginning of lactation, Normande cows the smallest decrease, and Montbéliarde cows an intermediate decrease. It can be noted from our results that the magnitude of milk Ca content variation during lactation was negatively related between breeds to the amount of Ca secreted daily in milk. To explain this, we hypothesized that the larger drop in Ca content at the beginning of lactation in breeds with higher amounts of $\mathrm{Ca}$ secreted daily in milk could be explained by a greater solicitation of operating organs involved in the regulation of calcemia, including the mammary gland. Indeed, it has been observed in mice (VanHouten et al., 2004) that the milk Ca content could decrease to increase calcemia in cases of hypocalcemia. If we assume that such mechanisms exist in dairy cows, a reduction in milk $\mathrm{Ca}$ content could be a mechanism for cows with high milk production to maintain their calcemia. This reduction of $\mathrm{Ca}$ content would result from the detection of an insufficient Ca supply by the Ca receptor of the mammary epithelial cells that would induce a secretion of PTHrP by the mammary gland. The PTHrP could then increase bone Ca mobilization (VanHouten et al., 2004; Kovacs, 2005). After mo 2 of lactation, we can assume that the decrease in milk production and amount of Ca secreted daily in milk would likely result in a lower need for Ca mobilization from bone and possibly in a lower reduction of Ca secretion by the mammary gland, which might explain the limitation of the Ca content drop. In this scenario, the increase of $\mathrm{Ca}$ content after mo 4 of lactation, which occurred at the same time for every breed, could also be related to the continuous decrease in the total amount of Ca secreted daily in milk during lactation.

A decrease in milk Ca content with the parity of the cow has been described by Kume and Tanabe (1993) in colostrum. In our experiment, milk Ca content decreased with parity regardless of the stage of lactation. This result may not be dissociated from the fact that older cows are known to have greater difficulty in mobilizing $\mathrm{Ca}$ from bone and in absorbing $\mathrm{Ca}$ from their digestive tract and are therefore more susceptible to postpartum hypocalcemia (Horst, 1986; Reinhardt et al., 2011). It might be assumed that in those cows a decrease in Ca secretion by the mammary gland could be a more important mechanism to conserve $\mathrm{Ca}$ and to regulate calcemia than in younger cows, according to the mechanism previously described in mice by VanHouten et al. (2004); this mechanism would even be amplified if we considered that the amount of $\mathrm{Ca}$ secreted daily in milk is higher in older cows.

\section{Effect of Feeding Strategy and Seasonality on Milk Ca Content}

The data obtained from the PhénoFinLait program were very useful in our study to characterize the effects of season, stage of lactation, and cow diets on milk Ca content and to dissociate them from each other as much as possible. Our objective was to explain the discrepancy observed between studies by characterizing the effect of the stage of lactation or season on milk Ca content that was likely linked to a partial confusion between these 2 parameters (Toffanin et al., 2015b; Chassaing et al., 2016). In our case, seasonality was sufficiently uncorrelated with the stage of lactation to consider that the variations in milk Ca content according to the stage of lactation that we observed were independent of the season and may also be independent of the feeding strategy, as calving dates were distributed equally between strategies.

However, we also showed that, at least in the context of milk production in France, the effects of the feeding strategy and seasonality on milk production parameters could not be totally dissociated. Indeed, our study confirmed that the cow diets are very specific to season and region in relation to climate parameters controlling the supply of certain forage types (Figure 4). We made a choice to characterize the effect of annual feeding strategy on milk Ca content rather than that of individual cow diets, as they were described previously in the PhénoFinLait program (Gelé et al., 
2014). The main advantage of that choice was to include potential delayed and remnant effects of diets on the phosphocalcic metabolism of cows, and thus milk Ca content, which could be inferred given the duration of the bone accretion or resorption cycles during lactation and gestation in cows (Ekelund et al., 2006; Taylor et al., 2009). Another advantage was the ability to use a complete block design between feeding strategy and calendar month.

We clearly showed an effect of the feeding strategy on milk $\mathrm{Ca}$ content that has been rarely described in the literature. Milk Ca content was often lower with diets based on pasture or conserved grass, such as silage or hay, than with diets based on corn silage. This was observable in our study in the winter and the spring in Montbéliarde cows and in the summer in Normande and Holstein cows. The difference in milk $\mathrm{Ca}$ content between diets could be high, with a difference between corn silage and hay of approximately $50 \mathrm{mg} / \mathrm{kg}$ in Montbéliardes. Hurtaud et al. (2014) also reported lower Ca content in cows grazing or fed conserved grass than in cows fed corn silage, although the difference was not significant. Poulsen et al. (2015) suspected an effect of cow diet on the milk Ca content, but did not have records of their diet. Chassaing et al. (2016) noticed milk Ca content variations possibly linked to the effect of the diet, but the effect of the diet was confused with a lot of other environmental effects in our study.

Because March to April is a major period of pasture turnout between winter diets and grazing, the drop in milk $\mathrm{Ca}$ content systematically observed during that period for the 3 breeds could also be linked, at least partly, to the nature of the diets fed to the cows. This would confirm the idea that milk Ca content is lower when cows are fed fresh or conserved grass rather than corn silage. Such an effect of the month of the year has been described previously, with higher milk Ca content in winter than in summer (Poulsen et al., 2015; Chassaing et al., 2016). It is impossible to confirm that it is not also linked at least partially to seasonal specificities, such as climatic conditions or day length. However, Boudon et al. (2016) found that increased day length increased $\mathrm{Ca}$ content in milk, but the increase they measured could only explain a small part of the drop observed between March and April. The drop in milk Ca content between March and April could also be explained by the increase in milk yield, and thus the increased demand for Ca secretion in milk, that occurred between February and April (data shown in Holstein cows; Figure 6). The concomitance of these 2 phenomena, the decrease of milk Ca content and the increase of the amount of Ca secreted daily in milk, is consistent with the hypothesis that Ca content could be a mechanism to regulate calcemia by decreasing the amount of
Ca secreted in a given milk yield (VanHouten et al., 2004). A maximal milk yield in March is understandable, given that, in the French dairy system, March is a period of high nutrient supply due to the association of good quality of grazed herbage and supplementation with winter diets. If a decrease in milk Ca content can occur quickly to regulate calcemia when the milk yield increases, a delay in the increase in milk Ca content occurs when the milk yield decreases. Indeed, this is illustrated by the fact that the decrease in milk yield in July occurred with all feeding strategies, and the amount of Ca secreted daily in milk (Figure 6) was thus only accompanied by a delayed increase in milk Ca content in August.

The fact that one of the chief functions of casein micelles in milk could be to solubilize the $\mathrm{Ca}$ and phosphate and avoid the formation of insoluble precipitates (Farrell et al., 2006) implies that the milk micellar Ca-to-soluble Ca ratio and the milk total Ca content-to-protein content ratio should vary within a very narrow range (Alais, 1984; Gaucheron, 2005). Our results showed that the milk total Ca content-toprotein content ratio can vary according to the diet of the cows, the season, or both, from 35 to $40.2 \mathrm{mg} / \mathrm{g}$. These results tempered the idea that the milk total Ca content-to-protein content ratio is constant and that the main determinant of milk $\mathrm{Ca}$ content is the casein content. The reasons for the variation in the milk total Ca content-to-protein content ratio are unclear. It would have been very useful to know the micellar and soluble Ca contents in the milk in our study, but MIR equations to predict micellar and soluble Ca were not developed. These results raised the question of the interaction of the systemic regulation and secretion of $\mathrm{Ca}$ in milk via the Ca receptor and the regulation of the partition of $\mathrm{Ca}$ in the mammary epithelial cells between the Golgi apparatus and the cytoplasm (Kovacs, 2016). We did not observe any effect of the breed on the milk total Ca content-to-protein content (data not shown), in contrast to what was previously observed (Alais, 1984; Gaucheron, 2005).

We have shown that, even though genetics is considered the major determinant of Ca milk content in cows, nongenetic factors also affect milk Ca content. In our study, variations in milk Ca contents due to stage of lactation or interacting effects of seasonality and diet could even be higher than differences between breeds. High heritability of milk Ca content has been shown in the literature by van Hulzen et al. (2009) and Buitenhuis et al. (2015). The heritabilities they obtained differed between breeds, with a higher heritability for Holsteins (0.72) than for Jerseys (0.63; Buitenhuis et al., 2015), but also differed between studies. Toffanin et al. (2015b) found a low heritability for milk 
Ca content (0.11), but data they used included more environmental sources of variability in milk Ca content with a higher diversity of sampling seasons, parities, or diets. Heritability is always estimated as the ratio between variance due to individual and the sum of variance due to individual and residual variance after correction for nongenetic factors (i.e., environment and physiological status; van Hulzen et al., 2009). Thus, a high heritability of milk Ca content in studies where environmental factors of variation of milk Ca contents are well controlled or described can be associated with a high variability of milk Ca content due to nongenetic factors.

\section{CONCLUSIONS}

This study illustrated that genetics is not the only factor that affects Ca content in bovine milk. The stage of lactation, parity, seasonality, and cow diet, and more specifically the nature of the forage, also explained a significant range of variation in milk Ca content. Variations in milk Ca content within a single lactation can be at least as important, depending on the breed, as the variations between breeds at the same stage of lactation. Cow diet and seasonality had lesser effects on milk Ca content than breed or stage of lactation, but these effects remained non-negligible. However, differences in milk Ca content due to parity were small compared with those explained by the factors previously cited, with a $5 \mathrm{mg} / \mathrm{kg}$ decrease in lactation. We also observed that those nongenetic factors affecting milk Ca content may be related to the fact that the mammary gland is also an organ involved in the Ca regulation of lactating cows, as well as bones, the digestive tract, and kidneys, suggesting that milk Ca content may be an easy way to follow the evolution of the Ca status of cows through lactation and between lactations. However, the observed effect of the cow diet and more specifically of the nature of the forages on milk Ca content remains to be explained. A remaining question is to determine whether this effect could be related to the Ca content of the diets, which could not be quantified with the required precision in this study.

\section{ACKNOWLEDGMENTS}

The PhénoFinLait project has received financial support from Agence Nationale de la Recherche (ANR, Paris, France, ANR-08-GANI-034 Lactoscan), APISGENE (Paris, France), Compte d'Affectation Spéciale Développement Agricole et Rural (CASDAR), Centre National Interprofessionnel de l'Economie Laitière (CNIEL, Paris, France), Établissement national des produits de l'agriculture et de la mer (FranceAgriMer,
Paris, France), France Génétique Elevage and the French Ministry of Agriculture. The equations for Ca content prediction were developed with the financial support of FranceAgriMer (FAVACAL Project, $\mathrm{n}^{\circ}$ 2013-0511) and with the help of Marion Ferrand (Institut de l'élevage, Paris, France) and Axelle Le Mouël (INRA). The authors also thank the Centre Mondial d'Innovation-Agro Innovation International (CMI-AII, Saint-Malo, France) and the Région Bretagne for financial support, and Anca Laza-Knoerr from CMI-AII and Karine Legrand from Phosphea (Dinard, France) for constructive discussion about the results in this paper.

\section{REFERENCES}

Abdi, H., L. J. Williams, and D. Valentin. 2013. Multiple factor analysis: Principal component analysis for multitable and multiblock data sets. Wiley Interdiscip. Rev. Comput. Stat. 5:149-179. https://doi.org/10.1002/wics.1246.

AFNOR NF ISO 8070. 2007. Lait et produits laitiers - Détermination des teneurs en calcium, sodium, potassium et magnésium - Méthode spectrométrie par absorption atomique.

Alais, C. 1984. Science du Lait: Principes des Techniques Laitières. SEPAIC. Société d'Edition et de Promotion Agro-alimentaires, Industrielles et Commerciales. Paris, France.

Boudon, A., M. Johan, A. Narcy, M. Boutinaud, P. Lamberton, and C. Hurtaud. 2016. Dietary cation-annion difference and day length have an effect on milk calcium content and bone accretion of dairy cows. J. Dairy Sci. 99:1527-1538. https://doi.org/10.3168/jds.2015 -9664 .

Buitenhuis, B., N. A. Poulsen, L. B. Larsen, and J. Sehested. 2015. Estimation of genetic parameters and detection of quantitative trait loci for minerals in Danish Holstein and Danish Jersey milk. BMC Genet. 16:52. https://doi.org/10.1186/s12863-015-0209-9.

Chassaing, C., C. Sibra, J. Verbič, O. M. Harstad, J. Golecký, B. Martin, A. Ferlay, I. Constant, C. Delavaud, C. Hurtaud, V. Ž. Pongrac, and C. Agabriel. 2016. Mineral, vitamin A and fat composition of bulk milk related to European production conditions throughout the year. Dairy Sci. Technol. 96:715-733. https://doi .org/10.1007/s13594-016-0300-7.

Cohen, J. 1988. Statistical Power Analysis for the Behavioral Sciences. 2nd ed. Routledge, Abingdon, UK.

Ekelund, A., R. Spörndly, and K. Holtenius. 2006. Influence of low phosphorus intake during early lactation on apparent digestibility of phosphorus and bone metabolism in dairy cows. Livest. Sci. 99:227-236. https://doi.org/10.1016/j.livprodsci.2005.07.001.

Escofier, B., and J. Pagès. 1994. Multiple factor analysis (AFMULT package). Comput. Stat. Data Anal. 18:121-140. https://doi.org/ 10.1016/0167-9473(94)90135-X.

Farrell, H. M., E. L. Malin, E. M. Brown, and P. X. Qi. 2006. Casein micelle structure: What can be learned from milk synthesis and structural biology? Curr. Opin. Colloid Interface Sci. 11:135-147. https://doi.org/10.1016/j.cocis.2005.11.005.

Ferrand-Calmels, M., I. Palhière, M. Brochard, O. Leray, J. M. Astruc, M. R. Aurel, S. Barbey, F. Bouvier, P. Brunschwig, H. Caillat, M. Douguet, F. Faucon-Lahalle, M. Gelé, G. Thomas, J. M. Trommenschlager, and H. Larroque. 2014. Prediction of fatty acid profiles in cow, ewe, and goat milk by mid-infrared spectrometry. J. Dairy Sci. 97:17-35. https://doi.org/10.3168/jds.2013-6648.

Flynn, A., and K. Cashman. 1997. Nutritional Aspects of Minerals in Bovine and Human Milks. P.F. Fox, ed. Springer US, New York, NY.

Gaucheron, F. 2005. The minerals of milk. Reprod. Nutr. Dev. 45:473483. https://doi.org/10.1051/rnd:2005030.

Gelé, M., S. Minery, J.-M. Astruc, P. Brunschwig, M. Ferrand-Calmels, G. Lagriffoul, H. Larroque, J. Legarto, O. Leray, P. Martin, G. Miranda, I. Palhiere, P. Trossat, and M. Brochard. 2014. Phé- 
notypage et génotypage à grande échelle de la composition fine des laits dans les filières bovine et caprine. INRA Prod. Anim. $27: 255-268$.

Hermansen, J. E., J. H. Badsberg, T. Kristensen, and V. Gundersen. 2005. Major and trace elements in organically or conventionally produced milk. J. Dairy Res. 72:362-368. https://doi.org/10.1017/ S0022029905000968.

Hidiroglou, M., and J. G. Proulx. 1982. Factors affecting the calcium, magnesium and phosphorus content of beef cow milk. Can. J. Comp. Med. 46:212-214.

Horst, R. L. 1986. Regulation of calcium and phosphorus homeostasis in the dairy cow. J. Dairy Sci. 69:604-616. https://doi.org/10 $.3168 /$ jds.S0022-0302(86)80445-3.

Horst, R. L., J. P. Goff, and T. A. Reinhardt. 1997. Calcium and vitamin D metabolism during lactation. J. Mammary Gland Biol. Neoplasia 2:253-263.

Hurtaud, C., M. Dutreuil, M. Coppa, C. Agabriel, and B. Martin. 2014. Characterization of milk from feeding systems based on herbage or corn silage with or without flaxseed and authentication through fatty acid profile. Dairy Sci. Technol. 94:103-123. https:// doi.org/10.1007/s13594-013-0147-0.

Husson, F., and J. Josse. 2013. Handling missing values in multiple factor analysis. Food Qual. Prefer. 30:77-85. https://doi.org/10 .1016/j.foodqual.2013.04.013.

Kaufmaan, W., and H. Hagemeister. 1987. Composition of milk. Chapter 4 in Dairy-Cattle Production. H. O. Gravert, ed. Elsevier, Amsterdam, the Netherlands.

Kovacs, C. S. 2005. Calcium and bone metabolism during pregnancy and lactation. J. Mammary Gland Biol. Neoplasia 10:105-118. https://doi.org/10.1007/s10911-005-5394-0.

Kovacs, C. S. 2016. Maternal mineral and bone metabolism during pregnancy, lactation, and post-weaning recovery. Physiol. Rev. 96:449-547. https://doi.org/10.1152/physrev.00027.2015.

Kume, S., and S. Tanabe. 1993. Effect of parity on colostral mineral concentrations of Holstein cows and value of colostrum as a mineral source for newborn calves. J. Dairy Sci. 76:1654-1660. https:// doi.org/10.3168/jds.S0022-0302(93)77499-8.

Malacarne, M., P. Franceschi, P. Formaggioni, S. Sandri, P. Mariani, and A. Summer. 2014. Influence of micellar calcium and phosphorus on rennet coagulation properties of cows milk. J. Dairy Res. 81:129-136. https://doi.org/10.1017/S0022029913000630.

Nakache, J.-P., and J. Confais. 2004. Approche Pragmatique de la Classification: Arbres Hiérarchiques, Partitionnements. Editions Technip, Paris, France.

Poulsen, N. A., I. Rybicka, H. D. Poulsen, L. B. Larsen, K. K. Andersen, and M. K. Larsen. 2015. Seasonal variation in content of riboflavin and major minerals in bulk milk from three Danish dair- ies. Int. Dairy J. 42:6-11. https://doi.org/10.1016/j.idairyj.2014 10.010 .

R Development Core Team. 2013. R: A language and environment for statistical computing. R Foundation for Statistical Computing, Vienna, Austria. http://www.R-project.org.

Reinhardt, T. A., J. D. Lippolis, B. J. McCluskey, J. P. Goff, and R. L. Horst. 2011. Prevalence of subclinical hypocalcemia in dairy herds. Vet. J. (Lond.) 188:122-124. https://doi.org/10.1016/j.tvjl 2010.03 .025

Sanchez, M. P., A. Govignon-Gion, M. Ferrand, M. Gelé, D. Pourchet, Y. Amigues, S. Fritz, M. Boussaha, A. Capitan, D. Rocha, G. Miranda, P. Martin, M. Brochard, and D. Boichard. 2016. Wholegenome scan to detect quantitative trait loci associated with milk protein composition in 3 French dairy cattle breeds. J. Dairy Sci. 99:8203-8215. https://doi.org/10.3168/jds.2016-11437.

SAS Institute. 2013. SAS Institute. SAS/STAT User's Guide, SAS Institute Inc., Cary, NC.

Soyeurt, H., D. Bruwier, J.-M. Romnee, N. Gengler, C. Bertozzi, D. Veselko, and P. Dardenne. 2009. Potential estimation of major mineral contents in cow milk using mid-infrared spectrometry. J. Dairy Sci. 92:2444-2454. https://doi.org/10.3168/jds.2008-1734.

Taylor, M. S., K. F. Knowlton, M. L. McGilliard, W. S. Swecker, J. D. Ferguson, Z. Wu, and M. D. Hanigan. 2009. Dietary calcium has little effect on mineral balance and bone mineral metabolism through twenty weeks of lactation in Holstein cows. J. Dairy Sci. 92:223-237. https://doi.org/10.3168/jds.2008-1345.

Toffanin, V., M. De Marchi, N. Lopez-Villalobos, and M. Cassandro. 2015a. Effectiveness of mid-infrared spectroscopy for prediction of the contents of calcium and phosphorus, and titratable acidity of milk and their relationship with milk quality and coagulation properties. Int. Dairy J. 41:68-73. https://doi.org/10.1016/j .idairyj.2014.10.002.

Toffanin, V., M. Penasa, S. McParland, D. P. Berry, M. Cassandro, and M. De Marchi. 2015b. Genetic parameters for milk mineral content and acidity predicted by mid-infrared spectroscopy in Holstein-Friesian cows. Animal 9:775-780. https://doi.org/10.1017/ S1751731114003255.

Van Hulzen, K. J. E., R. C. Sprong, R. van der Meer, and J. M. van Arendonk. 2009. Genetic and nongenetic variation in concentration of selenium, calcium, potassium, zinc, magnesium, and phosphorus in milk of Dutch Holstein-Friesian cows. J. Dairy Sci. 92:5754-5759. https://doi.org/10.3168/jds.2009-2406.

VanHouten, J., P. Dann, G. McGeoch, E. M. Brown, K. Krapcho, M. Neville, and J. J. Wysolmerski. 2004. The calcium-sensing receptor regulates mammary gland parathyroid hormone-related protein production and calcium transport. J. Clin. Invest. 113:598-608. https://doi.org/10.1172/JCI18776. 